\title{
Pismo KATASTROFY W XIX WiEKU WSTĘP DO ROZWAŻAŃ
}

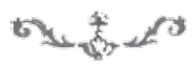

\section{ARGUMENT}

$\mathrm{P}$ ISZĄCEMU TE SŁOWA przemknęła myśl o tytułowej tematyce, gdy 12 września 2001 roku ujrzał na Krakowskim Przedmieściu orszak manifestacyjny prowadzony przez prominentnego dzisiaj polityka. Uczestnicy nieśli tabliczki z napisem: „Oto kara za świat bez Boga” i śpiewali religijne pieśni. Zastanawiało go, do jakiej tradycji przypisać to wydarzenie i słowa na transparentach: do polskiej romantycznej, w której Bóg gotów jest wysadzić planetę jak Julian Ordon redutę, i w której Chrystus ratuje in extremis cywilizację europejską, rażąc spojrzeniem jej destruktorów, jak Pankracy i wspólnicy? Czy też bezpośrednio do odwiecznego imaginarium karzącej opatrzności, z którego do dziś wyrastają idee w taki czy inny sposób prowidencjalistyczne?

Temat katastrofy dotyka wszystkich obszarów historii: politycznych, społecznych, gospodarczych, kulturowych - pisze specjalista od katastrof, Philippe Joutard. - Przez zachowania ludności przed katastrofami, w ich trakcie i po nich, postawę władz, wspomnienia zachowane $\mathrm{w}$ przekazie słownym i w źródłach pisanych objawia wyjątkowo dobrze funkcjonowanie społeczeństwa: pozwala odsłonić inną postać wydarzeń, których skutki mogą okazać się znacznie silniejsze niż skutki wydarzeń czysto politycznych. ${ }^{1}$

Od trzech dekad obserwujemy wzmożone zainteresowanie dyskursem katastrofologicznym, zarówno kulturową historią katastrof, jak i teorią kata-

$\mathrm{Ph}$. Joutard, Introduction. Un chantier prometteur, w: Histoire et mémoire des risques naturels, sous la dir. de R. Favier et A.M. Granet-Abisset, Grenoble 200o, s. 12; tłum. - M.B. 
strof w naukach ekonomicznych, społecznych, politycznych, a także w badaniach geologicznych. W tych ostatnich ożywiona jest do tego stopnia, że „katastroficzna wizja historii Ziemi wraca na światło dzienne”2. Trwają zacięte spory interpretacyjne, metodologiczne i terminologiczne, nawet samo słowo „katastrofa” ma różne użycia. W tej bardzo ogólnej i okrojonej prezentacji problemu używam je - i tak na ogół postępują badacze zainteresowani kulturowym wymiarem zjawiska - w pojęciu szerokim, obejmującym zarówno klęski żywiołowe, jak wypadki techniczne.

Historiografia katastrof w czasach nowożytnych kształtowała się wokół dwóch podstawowych i odmiennych problemów historycznych: wokół procesu laicyzacji natury, pozwalającego przejść od idei dopustu bożego, opatrznościowej interwencji do zjawisk fizycznych, oraz wokół rosnącej roli nowoczesnego państwa $\mathrm{z}$ jego projektem poskromienia natury. Ten pierwszy proces nie jest aż tak jednoznaczny i progresywny. Idee prowidencjalistyczne, choć osłabione, nigdy nie zostały wyparte i powracały nieraz ze zdwojoną siłą. Ten drugi proces, czyli postępująca etatyzacja, „upaństwowienie” katastrofy, wiąże się z formowaniem - wedle modnego dzisiaj określenia - „społeczeństwa ryzyka”, takiego, które organizuje się i integruje wobec zagrożeń i wobec woli ochrony przed nimi. Kiedy w jednym z pierwszych wykładów paryskich Adam Mickiewicz, kreśląc idealny obraz pejzażu słowiańskiego, mówi przy okazji: „Nie mamy tam ani skał utrudniających uprawę, ani powodzi, ani zalewów morskich, które zresztą pobudzają przedsiębiorczość człowieka i zachęcają go do walki”", wypowiada właśnie credo społeczeństwa ryzyka, w XIX wieku dość dobrze już zorganizowanego, wykorzystującego katastrofę do wytwarzania więzi i rozumiejącego, jak to określa filozof Serge Margel, „opatrznościową ekonomię katastrofy”.

\section{WIEK XVIII}

Katastrofalny wybuch wulkanu Tambora w Indonezji w roku Waterloo należał do najsilniejszych w dziejach. Według klimatologów wkrótce zaobserwowano w Europie niezwyczajne zjawiska optyczne, w tym wyjątkowo barwne i przedłużone zachody słońca; miały mieć one kolorystyczny wpływ na ob-

E. Buffetaut, La fin des dinosaures. Comment les grandes extinctions ont façonné le monde vivant, Paris 2003, s. 202; tłum. - M.B.

3 Por. U. Beck, Société du risque, Paris 2008.

4 A. Mickiewicz, Wykład V, w: tegoż, Dzieła. Wydanie Rocznicowe, t. 8: Literatura słowiańska. Kurs pierwszy, oprac. J. Maślanka, Warszawa 1997, s. 60.

5 Por. S. Margel, La société du spectral, Paris 2012. 
razy Williama Turnera ${ }^{6}$. Parę miesięcy później odnotowuje się spadek temperatury, który miał być wywołany wulkanicznymi chmurami. Lato 1816 roku było wyjątkowo chłodne, a zbiory wyjątkowo niskie. Byronowskim wizjom ciemności kryjących ziemię, powstałym w tymże roku, znanym u nas z transkrypcji Adama Mickiewicza i Zygmunta Krasińskiego, przypisuje się również wpływ ówczesnej pogody, ówczesnych widoków i nastrojów. Pod pędzlem Turnera i piórem Byrona katastrofa może być posępnie piękna, wzniośle dramatyczna, to dla nas oczywista wiedza o romantycznych upodobaniach estetycznych, choć często zapomina się o ich meteorologicznych uwarunkowaniach.

François-René de Chateaubriand narzekał w Pamiętnikach w 1832 roku, czytając opisy marsylskiej epidemii dżumy, że świat katastrofy został sprowadzony do raportów medycznych i katastrofa jest dopustem bez wyobraźni. On sam będzie więc ukazywał w prozie poetyckiej możliwości jej literackiej ekspresji . Ale Chateaubriand nie doceniał poprzedników. Kataklizm przychodzi dla Byrona i jego pokolenia jako coś już dobrze znanego w tym sensie, że wymyślonego, to znaczy ustalonego jako istotny przedmiot refleksji przez niedawną przeszłość, wiek XVIII. O pięknie katastrofy pisał wprost Edmund Burke, o jej roli w dziejach cały zastęp badaczy i filozofów, stąd prosta droga wiodła do romantycznych teorii i doznań wzniosłości, do pozatranscendentalnej resakralizacji natury. Solidny, fundamentalny dyskurs o katastrofach narodził się w Oświeceniu i jest podstawą dzisiejszych rozważań katastrofologów - do tego stopnia, że parafrazując Jeana Starobinskiego, mówi się właśnie o „wynalazku katastrofy” w XVIII wieku, choć oczywiście zapisy o katastrofach realnych i fikcyjnych pojawiały się w wiekach wcześniejszych ${ }^{8}$.

Wiek XIX, a zwłaszcza jego pierwsza połowa, nie przyciąga aż tak dużej uwagi katastrofologów jako dziedzic istotniejszego z tego punktu widzenia wieku poprzedniego. Natomiast w jego czasowej ramie widać, jak względem katastrofy wytwarzają się podwaliny społeczeństwa nowoczesnego. Z jednej strony - na przykład - wokół klęsk żywiołowych, a także wielkich wypadków pojawia się i cementuje zjawisko solidarności społecznej. Od czasów napoleońskich gazety odnotowują na przykład dary złożone ofiarom kataklizmów przez arystokratów, później przez całe wspólnoty9.

6 Por. F. Walter, Catastrophes. Une histoire culturelle XVI ${ }^{e}-X X I^{e}$ siècle, Paris 2008, s. 109-110.

7 Por. A.M. Mercier-Faivre, Ecrire la catastrophe, w: L'Invention de la catastrophe au XVIII siècle, sous la dir. A.M. Mercier-Faivre et Ch. Thomas, Genève 2008, s. 7-30.

8 Por. L'Invention de la catastrophe au XVIII siècle.

9 „Hrabia Remusat, najwyższy dozorca widowisk przesłał prefektowi departamentu Ourthe, gdzie leży Leodium - informuje "Gazeta Warszawska» wiosną 1812 roku - 2000 franków złożonych przez aktorów Teatru Francuskiego, płatnych od Cesarza na 
Wykształca się również nowoczesna socjotechnika władzy. Od lat czterdziestych na miejsce klęsk i wypadków będą udawali się prefekci, burmistrzowie, a później królowie, prezydenci i cesarzowie. Bryluje w tym Napoleon III, przedstawiany często $\mathrm{w}$ prasie w pozie zatroskania nad ofiarami czy w zadumie na wale przewcipowodziowym. Stał się on - dzięki szybkim połączeniom kolejowym - specjalistą od tak zwanych voyages compasionnels, „podróży współczucia" ${ }^{10}$. Katastrofa postrzegana jako zewnętrzna agresja staje się wydarzeniem, wobec którego należy podjąć działanie. Ma być obrobiona społecznie i kulturowo jako dramat - należy zająć się ofiarami, odtworzyć zniszczone miejsca, aby usunąć śmiertelne ślady, wytworzyć wspomnienie i wprowadzić je w obowiązujący typ zbiorowej pamięci.

W rozważaniach osiemnastowiecznych, najłatwiejszych do sprawozdania, katastrofa wykształca się jako przedmiot refleksji globalnej, obejmującej prawidła istnienia świata. Każdy z wielkich autorów - Denis Diderot, Voltaire, Jean-Jacques Rousseau, Georges Leclerc de Buffon, Jean-Baptiste de Lamarck, w Niemczech Wilhelm Humboldt i Immanuel Kant - podaje swoją wersję rozumienia fenomenu katastrofy. Jak dobrze wiadomo, głównym, choć nie jedynym rozrusznikiem tej refleksji było trzęsienie ziemi i - wedle dzisiejszego określenia - tsunami, które zniszczyły Lizbonę w 1755 roku, i później, w nieco mniejszym stopniu, choć jeszcze bardziej tragiczna w skutkach, fala trzęsień ziemi w Kalabrii w 1783 i 1784 roku, dobrze udokumentowana ikonograficznie. W literaturze wczesnoromantycznej echa tych wydarzeń najmocniej będą słyszalne w prozie Heinricha von Kleista.

Samo francuskie słowo catastrophe jeszcze nie istnieje w jego późniejszym rozumieniu (słownik Émile'a Littrégo odnotuje je dopiero w połowie XIX wie$\mathrm{ku}$ ), raczej przeciera sobie ku niemu drogę. Powolne dopasowanie słowa do wydarzeń realnych, jak wspomniane trzęsienie ziemi, trwało bardzo długo. W bliskim naszemu dzisiejszemu pojęciu ma swą premierę w Listach perskich Monteskiusza, ale jeszcze przez dłuższy czas oznacza przede wszystkim termin teatralny, dotyczący poetyki tragedii, a konkretnie sposobu, w jaki intryga dobiega końca. Podobne jak powyżej użycie słowa „katastrofa” odnajdujemy w polszczyźnie. U Mickiewicza pojawia się ledwie dwa razy. Dawne słowniki polskie podają zbliżone do słowników francuskich znaczenie teatralne.

zaratowanie familii, które przez zalew kopalni przy Beaujonc osierociały. Do tej ofiary przyłączony był list z podpisami aktorów Teatru Francuskiego” („Gazeta Warszawska” 1812, nr 34 Z 28 kwietnia, s. 596).

10 Por. F. Caille, Les héros du devoir. Presse populaire et traitement médiatique des catastrophes au XIX siècle, w: Récits et représentations des catastrophes depuis l'Antiquité, sous la dir. R. Favier et A.M. Granet-Abisset, Grenoble 2005, s. 307-327. 


\section{GEORGES CUVIER I KATASTROFIZM}

Moją ulubioną romantyczną minikatastrofą, niewielkim wypadkiem jest pożar ośki w powozie, którym Antoni Edward Odyniec z Eustachym Januszkiewiczem jechali z Petersburga do Wilna - gaszony przez dzielnych podróżników „trzema butelkami najwyborniejszego lafita, w które książę Witggenstein zaopatrzył na drogę ulubieńca swego Eustachego" "11, ale muszę zacząć od katastrofy nieco większej, od biblijnego potopu, gdyż bez historii Ziemi, ówczesnego hobby intelektualnego, tematu nawet salonowych dyskusji, ani rusz. „Była to epoka - wspomina Ignacy Domeyko swe czasy paryskie - w której najmłodsza $\mathrm{z}$ nauk geologia, osierocona od mistrza swego Cuviera, zawracała głowy turystom i w ogólności dyletantom nauki”"

W pierwszym czterdziestoleciu XIX wieku mamy jedną, wielopostaciową teorię katastrofy i jedną, wielopostaciową jej refutację. Pojęcie katastrofy wiąże się ze słownictwem geologicznym, rozpowszechnionym przez pisma Cuviera i wielu innych badaczy. Jego teoria, przypomnę, zakładała, że przemiany na Ziemi są wynikiem gwałtownych geologicznych kataklizmów, dotykających powierzchni całego globu i pociągających za sobą masową destrukcję gatunków. Cuvier posługuje się naprzemiennie synonimicznymi dla niego określeniami „katastrofa” oraz - częściej - „rewolucja”, które to słowo wyszło już wówczas poza astronomiczne znaczenie i zaczęło mieć równocześnie polityczne oraz geologiczne użycie. Samego pojęcia „katastrofizm” na określenie myśli Cuviera - opracowywanej na przełomie wieków, po raz pierwszy sformułowanej dość zwięźle w 1812 roku i rozpisanej na długie tomy kilkanaście lat później w 1825 - użył w 1837 roku angielski filozof nauki i historyk William Whewell (w Anglii pisma Cuviera cieszyły się nadzwyczajnym powodzeniem). Myśli Cuviera sprzeciwiali się zwolennicy poglądów określanych jako transformizm bądź gradualizm (a nawet aktualizm), stawiających tezę o jednolitym i stopniowym przeobrażaniu się Ziemi. Najpełniej wyraził je w roku 1830 Charles Lyell w swej pracy Principles of Geology, ale już wcześniej były one $\mathrm{w}$ dość szerokim użyciu. $\mathrm{Z}$ tej grupy wyobrażeń i rozpoznań droga prowadzi do teorii Charlesa Darwina ${ }^{13}$.

11 A.E. Odyniec, Listy z podróży, oprac. M. Toporowski, wstęp M. Dernałowicz, t. 1, Warszawa 1951, s. 52.

12 I. Domeyko, Moje podróże. Pamiętniki wygnańca, wstęp i oprac. E.H. Nieciowa, t. 1, Wrocław 1963, s. 194.

13 Szerzej na ten temat zob.: C. Baubin, Autour du catastrophisme. Des mythes et légendes aux sciences de la vie et de la terre, Paris 2005; C. Larrère, Catastrophes ou Révolution: les catastrophes naturelles ont-elles une histoire?, w: L'Invention de la catastrophe au XVIII siècle, s. 133-157. 
Według Cuviera, w dziejach globu zdarzyły się cztery wielkie kataklizmy. Ostatnim był potop, który Cuvier sytuował na jakieś pięć, sześć tysięcy lat przed narodzinami Chrystusa. Kolejna katastrofa miała być kwestią - być może bardzo długiego - czasu. Spór dotyczący idei o wielkich katastrofach i idei o rozłożonych w czasie przemianach nie był już wówczas nowy. Idee te rozważali na różne sposoby Buffon, Holbach czy Boulanger. Oryginalnym wkładem Cuviera było połączenie historii życia $z$ historią Ziemi i przeniesienie uwagi - dzięki pracom o eksterminacji gatunków - z geologii na zoologię i biologię.

Zatrzymam się na chwilę przy wątku dyluwialnym, tym bardziej że interesował on naszych ważnych czytelników teorii geologicznych: Joachima Lelewela i młodego Mickiewicza. Do dzisiaj trwają spory dotyczące wczesnoromantycznych, religijnych i naukowych zarazem interpretacji powodzi biblijnej dla rozwoju geologii. Niektórzy twierdzą, że były większym jej hamulcem niż opowieści o stworzeniu. Nie jest też całkiem jasne, czy dla samego Cuviera uznanie boskiej interwencji w dzieje Ziemi było tylko ukłonem w stronę ortodoksji, czy wyrazem przekonań. Jego interpretacja potopu, łącząca geologię $z$ religią, była jedną z kolejnych - dyluwializm wytworzył jeszcze przed Cuvierem ogromną liczbę tekstów, nie tylko naukowych, lecz także poetyckich. Klisz wokół naukowych wykładni potopu uznających opowieść biblijną i zarazem skupionych wedle ówczesnej poprawności politycznej nad geologiczną i klimatyczną wykładnią powstawało wciąż tyle, że trzeba było Gustave’a Flauberta, by je ośmieszył w Dykcjonarzu komunałów hasłem skamielina: „Skamielina: najlepszy dowód na potop".

Lelewel żywo interesuje się tą problematyką jeszcze jako student, pisząc rozprawkę - w tym okresie powstało w Europie kilkadziesiąt prac na ten temat - charakterystycznie zatytułowaną O przyczynie fizycznej potopu (o tym wątku wspomina ostatnio Danuta Zawadzka w znakomitej książce Lelewel i Mickiewicz. Paralela ${ }^{14}$ ). Lelewel, podobnie jak Cuvier, zakłada intencyjne działanie Stwórcy, lecz również cały przebieg kataklizmu bada wedle praw fizycznych, podając swoje hipotezy, które w dużej mierze dotyczą sił działających we wnętrzu Ziemi. Podejmuje polemikę z różnymi autorami niewymienionymi z nazwiska, łatwo jednak - chodzi o refutację tezy o uderzeniu komety oraz teorii przyspieszenia i spowolnienia biegu Ziemi - ich zidentyfikować.

Geologia interesowała Lelewela naukowca. Jeśli Mickiewicza nie interesowała w sensie dosłownie naukowym, to interesowała go jako dziedzina wiedzy odkrywająca mechanikę głębi, obejmującą swym działaniem całość

Por. D. Zawadzka, Lelewel i Mickiewicz. Paralela, Białystok 2013, s. 309-349. 
globu. „Nieraz miasto w podziemną rozpadlinę gruchnie...” - pisze poeta w wierszu Do Joachima Lelewela, a w dalszym, katastroficznym passusie utworu, w którym wymienia jednym tchem różne klęski żywiołowe, widać, że wiąże je przede wszystkim ze skrytymi ruchami Ziemi. Lelewel umie wyjaśnić:

\section{Jak się z przyczyny wspólnej różne skutki rodzą Jak podziemny wypadek morzem zakołata I niebieskiego sprawi zaburzenie świata. ${ }^{15}$}

Mickiewicz sam chętnie, jak wiemy, używa wyobrażeń potopu, nagłego zatopienia, określenia „przedpotopowy”. Widać - co podkreśla Zawadzka - że poetyckie obrazowanie jest o wiele bliższe naukowym spekulacjom niż frenezji czy baśniowości. Wyraźnie jest potrzebna Mickiewiczowi cezura w czasie - to, że w dziejach doszło do nagłego pęknięcia, dzielącego czas na "przed” $\mathrm{i}$ „po”. Potop też jest cezurą, cezurą historyczną, która nabiera z czasem cech cezury duchowej. Już w kursie pierwszym Literatury słowiańskiej Mickiewicz kładzie nacisk na fakt, że „kości zwierząt przedpotopowych” najwięcej można znaleźć na ziemiach słowiańskich ${ }^{16}$, co będzie miało wkrótce jakieś znaczenie dla dyskursu towianistycznego - wykład Mistrz kursu czwartego zaczyna się od rozważań nieszczęścia, jakie spadło na zwierzęta ${ }^{17}$.

\section{GEORGES CUVIER I NIECIĄGŁOŚĆ}

Katastrofistów (geologów, biologów i zoologów w jednym) pierwszej połowy XIX wieku dzieli przede wszystkim bardzo złożona kwestia ciągłości i nieciągłości, w której poszczególni badacze zajmują wobec stworzenia różne stanowiska, mówiące to o jego jednorazowości, to o jego powtarzalności, to o jego przeobrażalności. Cuvier miesza oba wymiary. Tkanka czasu byłaby ciągła, lecz przerywana, gdyż podziurawiona katastrofami, w których wyniku świat biologiczny doznał serii zerwań, rewolucji, co wyjaśnia nieciągłość gatunków zwierzęcych i obecność skamielin. Oświeceniowe widzenie świata chciało za wszelką cenę przenieść to, co nienormatywne, w sferę normatywności i we wszystkich kategoriach wiedzy szukało usilnie modelu pozwalającego sprowadzić do jednego porządku to, co pochodzi z nieporządku, z wypadku,

15 A. Mickiewicz, Do Joachima Lelewela. Z okoliczności rozpoczęcia kursu historii powszechnej w Uniwersytecie Wileńskim, dnia 9 stycznia 1822 r., w: tegoż, Dzieła..., t. 1: Wiersze, oprac. Cz. Zgorzelski, Warszawa 1997, s. 142-143.

16 Tenże, Wykład VIII, w: jw., t. 8, s. 91.

17 Por. tenże, Wykład X (Mistrz), w: jw., t. 11: Literatura słowiańska. Kurs czwarty, oprac. J. Maślanka, Warszawa 1998. 
z katastrofy. Było to widzenie oparte na bezkolizyjnej ciągłości. Dla Michela Foucaulta, który uznaje w Słowach i rzeczach Cuviera za najpotężniejszy umysł naukowy swych czasów, francuski paleontolog, stawiając kwestię nieciągłości, analizując na nowy sposób trwanie, ujawniając podobnie jak markiz de Sade zło natury, inicjuje nowy i najważniejszy sposób myślenia o historyczności „W momencie, gdy rozkwitała ona po raz pierwszy w wiedzy zachodniej”. Dzięki Cuvierowi nieciągłości, puste miejsca, braki, wyrwy przestają stanowić przeszkody, przestają być pozorami, które należało poprawić. Stają się one znakami, wyrw tych nie należało przeto wypełniać, lecz je zrozumieć ${ }^{18}$.

Poetą i Stwórcą nazywał Cuviera Honoré de Balzac. Teorie Cuviera miały wpływ na samą poetykę jego powieści, w tym sensie są też one postacią pisma katastrofy. Co prawda Balzacowi bliższe i bardziej potrzebne dla wyjaśniania zasad rządzących społeczeństwem były tezy ewolucjonistyczne, które czerpał od Étienne’a Geoffroya Saint-Hilaire’a, jednak inspirował się teorią katastrof przy konstrukcji fabuły. Dla Balzaca Cuvier jest poetą i kreatorem, gdyż jego wykład opiera się na zdarzeniach, które rwą linearny i ułożony czas. Więc on też wprowadzi we własną opowieść wydarzenia funkcjonujące jak katastrofy, które wstrząsają społeczną pozycją bohaterów.

\section{KOŃCE ŚWIATA, OSTATNI LUDZIE}

Wielką czytelniczką Cuviera - jako pisarza katastrof - była wcześniej Mary Shelley, która rozwinęła na swój sposób i doprowadziła do skrajności wątki apokaliptyczno-katastroficzne tak mocno obecne u Byrona (w Kainie Byron odwołuje się do Cuviera expressis verbis, jednocześnie zaznaczając, że nauka Cuviera nie jest sprzeczna z nauką Mojżesza: „Czytelnik zauważy, że świat został wielokrotnie zniszczony przed stworzeniem człowieka” ${ }^{19}$ ) i jej męża Percy'ego Shelleya, również czytelnika Cuviera, u którego - w Prometeuszu skowanym - nie brakuje powodzi i zgubnych uderzeń komet. Mary Shelley jest autorką obszernej powieści The Last Man, opisującej zagładę świata w wyniku epidemii dżumy, tyfusu i załamania klimatu. Dżuma - pomijam w mych uwagach szczegółowe wątki dotyczące zarazy w XIX wieku - działa jak bomba neutronowa - zabija ludzi, zostawiając nienaruszone ich dzieła i miasta. Dzieło kończy się, jak niemało dwudziestowiecznych powieści katastroficznych, niezwykle melancholijnym obrazem samotnej włóczęgi ostatniego człowieka Lionela Vernay po pustych wodach i brzegach Morza Śródziemnego.

18 Por. M. Foucault, Słowa i rzeczy, przeł. T. Komendant, t. 2, Gdańsk 2005, s. 66-87.

19 G.G. Byron, Kain. Misterium, przeł. J. Paszkowski, w: tegoż, Wybór dzieł, wyb., przedm., red. i przyp. J. Żuławski, t. 2, Warszawa 1986, s. 616. 
Wpływ na powieść Shelley miał także bardzo popularny w tym czasie (napisany w roku 1798) An Essay on the Principles of Population Thomasa Malthusa, w którym autor opisuje katastrofalne konsekwencje, do jakich doprowadzi przeludnienie miast.

Ziemia może zginąć śmiercią nie nadprzyrodzoną, lecz naturalną, pisał pierwszy Kartezjusz, śmiercią gwałtowną, przez zderzenie z kometą, albo śmiercią powolną, przez wygaśnięcie Słońca. W XIX wieku temat nagłego końca świata, do którego dojdzie w wyniku katastrofy, wkracza mocno w imaginarium. Pominę tu długie wyliczenie wyobrażonych w literaturze nadchodzących katastrof ostatecznych, z których wiele mogłoby służyć za scenariusz do filmu Larsa von Triera, oraz renesans motywów pompejańskich z jedną $\mathrm{z}$ najbardziej poczytnych powieści dziewiętnastowiecznych na czele: The Last Days of Pompeii (1834) Edwarda Bulwera-Lyttona ${ }^{20}$. Wspomnę tylko, że teorie wygaśnięcia Słońca znane są na przykład Krasińskiemu, jak wiele innych teorii astrofizycznych i fizycznych. Jest on między innymi czytelnikiem prac Williama Herschela (jeśli chodzi o wizje kosmogoniczne i odkrycie mgławic, rozszerzenie kosmosu), Michaela Faradaya, Luigiego Galvaniego, Alessandra Volta (jeśli chodzi o teorie fizyczne). Ma on szczególną umiejętność przekładania ich na metaforykę, to miłosno-utopijną, to historiozoficzną - w obu chodzi o obrazowanie świata po jego ostatecznym przeobrażeniu, po kresie, który - w zależności od nastroju - okazuje się początkiem nowego istnienia lub ostateczną zagładą. Szczególnie pociągają Krasińskiego panteistyczne wyobrażenia ulatniania, skraplania, rozpraszania, rozdrabniania materii, tego, co by się stało po jej ostatecznym przetworzeniu: „[...] gdyby Bóg rozpuścił materię - pisał do Delfiny - gdyby się rozpadło wszystko na proch najdrobniejszy, na proch idealny, porwany siłami ruchu w przestrzenie, wszechświat by się wtedy zamienił w muzykę!”21.

Pominę tutaj również rolę i wyobrażenia katastrofy w pismach apokaliptyczno-palingenetycznych i mistycznych Krasińskiego, a także Juliusza Słowackiego, zwracając jedynie uwagę, że inspirujący Krasińskiego Pierre-Simon Ballanche, niewystarczająco u nas rozpoznany, był bardzo mocno z Cuvierem związany. W swych pismach posługiwał się - bardzo amatorsko - jego problematyką geologiczną i paleontologiczną. Do Krasińskiego teksty Ballanche’a docierają już w formie ostatecznej, oczyszczonej niejako, oderwanej od historii naturalnej i przełożonej na palingenetyczną filozofię dziejów. Krasińskie-

20 Por. H. Tuzet, Le thème de la fin du monde dans les lettres après 1660, w: Literature and Science. Proceedings of the Sixth Triennial Congress, Oxford 1955, s. 164-169.

21

List z 19 XII 1839, w: Z. Krasiński, Listy do Delfiny Potockiej, oprac. i wstęp Z. Sudolski, t. 1, Warszawa 1975, s. 8 o. 
go paleontologia, w przeciwieństwie do Mickiewicza, nie zajmowała, ale też inny, powiedzmy, obojętny czy arystokratyczny był jego stosunek do zwierząt.

Syndrom apokaliptyczno-tanatyczny, charakterystyczny dla wyobraźni Krasińskiego, ale też dla wyobraźni pierwszego pokolenia postnapoleońskiego, wzmacniającego traumy generacji wcześniejszej, uruchamiał obrazy powszechnego gorączkowego poruszenia, dotykającego wszelkich sfer życia. Dzieje ludzi i Ziemi, wystawione na wielkie żywioły nie wiedzieć czy niszczące, czy transformacyjne, poddane są solidarnie wstrząsom. Trzęsienia ziemi, epidemie, powodzie świadczą tu i teraz o gorączce czasów, którą wywołują i ludzie, i żywioły. „Coś tam naruszonego w organizmie planety - pisał Krasiński tym razem do Stanisława Małachowskiego - w ciele rodu ludzkiego, w mózgu Mickiewicza, w sercu naszym, na ziemi i na niebie, w powietrzu i na morzach wszędzie”22. Można tu mówić o imaginacyjnym przyśpieszeniu długiego trwania. Cuvier wielokrotnie podkreślał, że trwające na powierzchni globu procesy nie mają dość głębokich przyczyn, by wywołać w najbliższym czasie podobne do przeszłych katastrofy, których ślady odczytujemy. Ale wiemy dobrze, że literatura nie ma czasu, by czekać.

Na szczęście byli też tacy, jak Domeyko. Domeyko uczęszczał na wykłady Pierre’a-Louisa-Antoine’a Cordiera, ucznia Cuviera.

$\mathrm{Z}$ wielką przyjemnością go słuchałem. Pamiętam jednak, że wcale nie byłem rad z jego ostatniej lekcji, na której, streszczając cały swój kurs, wywodził głównie zmiany i przeobrażenia, przez jakie przeszła kula ziemska od stworzenia; - a kiedy po tym przeglądzie całej kolei geologicznych epok przyszedł mimo wszystko do wniosku o nieuniknionym końcu i zniszczeniu, jakie spotka koniecznie naszego planety, nie umiał się z tej fatalnej konsekwencji inaczej wywinąć, jak zapowiadając, że to nie może nastąpić, chyba że za wiele, wiele wieków, i nie warto o tym myśleć. ${ }^{23}$

\section{KATASTROFY MORSKIE I INNE WYPADKI}

Warto myśleć o tym, co za oknem, albo o tych, co na morzu. Pod koniec lat pięćdziesiątych XIX wieku „Gazeta Warszawska” donosiła:

Przemysł morskich transportów, który nazwać by można wielką bitwą człowieka $\mathrm{z}$ morzem, poniósł w ubiegłym 1858 roku znaczne straty. Liczą w przybliżeniu, że 30 ooo statków kupieckich wszelkiego rozmiaru, rodzaju, objemu i narodowości puszczało się w 1858 na ogromne masy wody oblewającej trzy czwarte części naszego [sic!] planety. Z tej liczby zginęło ich 3073. [...] Cóż to za okropna danina, bo przechodzi 10 procent od sta. ${ }^{24}$

22 List z 1 VI 1845, w: Z. Krasiński, Listy do Stanisława Małachowskiego, oprac. i wstęp Z. Sudolski, Warszawa 1979, s. 74.

23 I. Domeyko, dz. cyt., s. 194-195.

24 Rozmaitości, „Gazeta Warszawska” 1859, nr 42 z 3 lutego, s. 5. 
Po czym następują szczegółowe statystyki katastrof wedle przyczyn i przynależności do narodowych bander.

Katastrofy morskie przyciągały uwagę bardziej niż inne katastrofy transportowe. Ze względu na ogromnie dynamiczny rozwój żeglugi międzyatlantyckiej ich liczba stale rosła. Typ katastrof zależy oczywiście od postępu technicznego. Powiedz mi, jaka zdarzyła się katastrofa, powiem ci, jaka stała za nią technika. Wymyślić techniczną innowację znaczy również wymyślić nowy rodzaj katastrofy. W tym przypadku większa szybkość okrętów, dzięki wynalazkowi maszyn parowych, i większa bezwładność zwiększonej masy potęgowały siłę ewentualnych zderzeń i kolizji.

W latach trzydziestych powstały pierwsze linie kolejowe - od razu bardzo oblegane - i zmienił się charakter wypadków komunikacyjnych. W bardzo rozwiniętym systemie transportu konnego było ich co niemiara. W samym 1832 roku we Francji zdarzyło się ich ponad cztery tysiące, jeden z takich wypadków - wypadek syna Ludwika Filipa - miał notabene przewidzieć Andrzej Towiański. Nastanie kolei żelaznej wpłynęło na statystyki - przez pierwszych kilkanaście lat praktycznie nie było jeszcze wykolejeń (ze względu na zbyt małą prędkość) ani zderzeń, ofiarami - ponad sto osób w samej Francji w pierwszych dwóch latach - byli przede wszystkim piesi. Szyny przechodziły nieraz przez środek miast i wiosek, ginęli oczekujący na peronach, śpiący na torach albo pasażerowie niebacznie wychylający się przez okna i drzwi wagonów (zdarzało się to tak często, że zarządzono zamknięcie tychże na klucz, jednak pożar, który wybuchł w 1842 roku w pociągu jadącym do Meudon, spowodował tyle ofiar niemających drogi ucieczki, że decyzję cofnięto). W prasie i literaturze drugorzędnej można śledzić równolegle $\mathrm{z}$ rozwojem kolei perypetie związane $\mathrm{z}$ ryzykiem (instrukcje: jak wsiadać i wysiadać z pociągu) i bezpieczeństwem (nie tylko ze względu na wypadki mechaniczne, ale też biologiczne; na przykład bardzo obawiano się złego powietrza w tunelach i mikrobów, kiedy już mikroby wykryto). Powstawało też od razu dużo poezji okolicznościowej związanej z koleją. Trzeba było dobrych czterdziestu lat, aby kolej wkroczyła do wielkiej literatury i wprowadziła tam swoje wypadki (Lew Tołstoj, Bolesław Prus, Émile Zola). W romantycznych pismach do 1850 roku jest ona bardzo nieznacznie obecna ${ }^{25}$.

Każdy typ katastrofy obrasta swoją literaturą dokumentalną i piękną. Można układać tematyczne antologie każdego z nich, zapewne katastrofa morska, osadzona w dziejach od dawna, przyniosłaby największą liczbę 
stron. Ani pożary, jak ten, ogromny w Krakowie w 1852 roku, ani trzęsienia ziemi nie wywoływały takich ech. Naszą „morską” literaturę dziewiętnastowieczną mógłby godnie reprezentować Domeyko opisujący dramatyczne utknięcie statku na mieliźnie u wybrzeży Brazylii czy uczestnik jednej z katastrof, Tomasz Teodor Jeż. Lubię zwłaszcza taki fragment jego wspomnień:

W chwili tej drzwi od kajuty kapitańskiej otworzyły się i odezwał się głos Łuniewskiego (kapitana): - Polecajcie się Bogu, bracia: rozbiliśmy się [...]. Wzuwałem buty. Mikułowski się odezwał: - Butów przecie nie wkładaj. - No jakże? - odparłem. - Ciężko ci będzie pływać, gdy się do wody wysypiemy. ${ }^{26}$

Jak przejść od konkretnych katastrof do ich zapisu literackiego? Jeden marynistyczny przykład: najbardziej znana sekwencja w tej serii wyobrażeń dotycząca wielokrotnie komentowanego opowiadania Cypriana Norwida Cywilizacja.

W wykładzie o Słowackim Norwid odwołuje się do obrazu odnalezionego w Legendzie Krasińskiego - który w swej korespondencji odnotowuje zresztą wszelkie zasłyszane katastrofy morskie - „wielkiego i posępnego okrętu bez płócień i masztów, a wszystkie fale kołami rozbija na pianę - i z pośrodka jego bucha słup dymu, który w nazad leci w nieskończoność" ${ }^{27}$. Norwid wykorzystuje ten symbol złowieszczej nowoczesności we własnym opowiadaniu, w którym przeciwstawiony dawnemu żaglowcowi statek parowy „Cywilizacja” idzie na dno. Należy pamiętać, że Norwid sam miał ciężką morską przeprawę do Ameryki, która skończyła się co prawda szczęśliwie w przeciwieństwie do podróży Margaret Fuller, lecz również miała być pełna perypetii (burza roztrzaskała maszty jego żaglowca koło Irlandii, widział wokół szczątki innych statków). W kilka lat po powrocie z Ameryki duże wrażenie sprawiła na nim wiadomość o katastrofie okrętu parowego „Pacific”, którym sam podróżował był do Europy - zaginął o nim wszelki ślad. W szczególności przejęła go wieść o odnalezieniu - niczym w niepowstałej jeszcze powieści Jules’a Verne’a - listu w butelce, napisanego przez jednego z rozbitków, niejakiego Grahama, który przed utonięciem zdążył wyjaśnić przyczynę katastrofy (zderzenie z górą lodową). Użycie motywu katastrofy, a zwłaszcza katastrofy morskiej, do celów alegorycznych to nie tak rzadki przypadek, wyobraźnia zbiorowa, nie tylko francuska, długo przechowywała pamięć o katastrofie „Meduzy” z 1816 roku,

26 T.T. Jeż (Zygmunt Miłkowski), Od kolebki przez życie. Wspomnienia, oprac. A. Lewak, wstęp A. Brückner, t. 2, Kraków 1936, s. 412.

27 C. Norwid, O Juliuszu Słowackim w sześciu publicznych posiedzeniach (z dodatkiem rozbioru „Balladyny”), w: tegoż: Pisma wszystkie, oprac. J.W. Gomulicki, t. 6: Proza, cz. 1, Warszawa 1971, s. 440 . 
upamiętnionej przez słynny obraz Théodore’a Géricaulta. Katastrofa „Meduzy” znalazła odbicie już w Byronowskim Don Juanie, później w powieści Salamandra Eugène’a Suego i wielu pomniejszych świadectwach po czasie. Wstrząsowi, jaki wywołała, niektórzy historycy przypisują powstanie powieści marynistycznej. Wspomnę tylko, że w jej pierwszym okresie rozwoju, do lat czterdziestych, dominuje poetyka sensacyjno-frenetyczna - opowieści skupiają się często na dramatycznych wypadkach i katastrofach (pożar na okrętach „Kent” i „Sophie”, zatonięcia wielkich okrętów wojskowych w tym słynnego „Droits de l'Homme" itd.), w tym czasie pojawiają się wielotomowe kompendia katastrof morskich, różnego rodzaju histoire des naufrages. W późniejszej literaturze marynistycznej wzmacnia się w nich motyw ludzkiego heroizmu ${ }^{28}$.

\section{RATOWNICY I HEROSI}

Ogólnie można powiedzieć, że katastrofa morska (zabójczy sztorm, rozbicie się), a także powódź (o XIX wieku historycy katastrof mówią, że był stuleciem powodzi) zajmuje uprzywilejowane miejsce w imaginarium pierwszej połowy XIX wieku. Ten typ katastrofy najlepiej uwidacznia również społeczną obróbkę katastrofy, charakterystyczną dla tego stulecia. Jednym z jej wymiarów jest lansowanie postawy obywatelskiej, opowieść o katastrofie jako zdarzeniu, w którym ujawnia się hart ducha i umiejętność poświęcenia się. Pojawia się modny, zarówno w prasie, jak i w literaturze felietonowej czy popularnej, a zwłaszcza w pismach ulotnych - dotyczy to nie tylko katastrof morskich, lecz także wszelkich innych - motyw ratowników, bohaterów, którzy z narażeniem życia rzucają się na pomoc innym. Typowa obróbka katastrofy przez druki ulotne w latach trzydziestych (na podstawie analizy prasowego rynku francuskiego) przewiduje następujące etapy opisu: opis katastrofy (naturalnej bądź spowodowanej przez działania ludzkie), przepadek mienia, straty osobowe, powszechna panika i trwoga, heroiczna postawa paru jednostek, gorliwa pomoc ze strony władzy ${ }^{29}$.

Ten pozytywny czy pozytywistyczny wątek jest na tyle ważny w takiej kulturze jak szwajcarska, że staje się on wręcz nie tylko przykładem pedagogicznym, lecz także mitem założycielskim dla narodowego stylu zachowań i stylu myślenia. Za jeden $\mathrm{z}$ fundamentów tego mitu uznaje się Wilhelma Tella Friedricha Schillera $\mathrm{z} 1804$ roku. W utworze tym mowa jest o dwóch zagrożeniach: obcy najeźdźcy i tyrani oraz klęski żywiołowe. Wilhelm Tell daje sobie radę

28 Por. M. Brosse, Littérature marginale: les histoires des naufrages, «Romantisme»1972, $\mathrm{n}^{\circ} 4$, s. $112-120$.

29 Szerzej na ten temat zob. F. Caille, dz. cyt., s. 307-319. 
z jednymi i drugimi, staje się ratownikiem, zbawcą, kimś, kto tworzy szwajcarską „wspólnotę dobrej woli” zmagającą się z groźną naturą. Dodam, że szwajcarskie opracowania katastrof i kataklizmów w XIX wieku są najdokładniej udokumentowane.

\section{PAMIĘĆ O KATASTROFACH}

O zapadnięciu się góry nad Lemanem, o którym wspomina Słowacki, pamięta się dobrze do dzisiaj. Pokazywano mi niedawno w Villeneuve, tam, gdzie mieszkał Słowacki, z którego miejsca przyszedł kataklizm.

W jaki sposób pamięć o katastrofie tworzy lokalne czy środowiskowe mitologie? Jak długo ta pamięć trwa w samym języku, na przykład pamięć o klęskach militarnych, jak Waterloo czy Berezyna - oba wyrażenia do dzisiaj używane są na oznaczenia klęski, to pierwsze w wielu językach, to drugie we francuszczyźnie.

Wspominałem przed chwilą o katastrofie „Meduzy”, teraz przykład alpejski. 20 sierpnia 1820 roku podczas jedenastej próby wejścia na Mont Blanc lawina zmiotła trzech przewodników. To zdarzenie przejdzie do historii jako „wypadek karawany doktora Hamela”, w skrócie „wypadek Hamela”, szefa wyprawy, mieszkającego w Petersburgu doradcy rządu rosyjskiego. Wypadek wywołał drobiazgowe śledztwo i wiele reperkusji w prasie. Dyskusja dotyczyła głównie odpowiedzialności za jego spowodowanie, którą obarczano to ślepy los, to przewodników, a przede wszystkim samego doktora Josepha Hamela. Obszernie o zdarzeniu informuje zwłaszcza brytyjska prasa, powstają na jego temat całe publikacje, które z pewnością w młodych głowach wzniecają iskrę przygody, w tym czasie zostaje też założony w Londynie Alpine Club. Również uczestnicy wypraw alpejskich przez kolejne lata dużo o wypadku piszą. Niektórzy docierają do bezpośrednich świadków wydarzenia, pozostałych przy życiu przewodników. Duży tekst o karawanie Hamela pisze Alexandre Dumas, a w 1835 roku, po swoim pobycie w Chamonix, młody John Ruskin. Wspomina o nim Jules Michelet, a pięćdziesiąt lat po wypadku parę stron poświęca mu także Mark Twain. Pierwsze przewodniki i podręczniki alpejskie powstałe po 1850 roku również o wypadku wspominają.

Po śmierci Hamela w 1862 roku ukazują się w prasie angielskiej nekrologi przypominające o zdarzeniu - wypadek ciągnął się za nim jak tren żałobny przez całe życie i nie opuszczał go po śmierci. Rok wcześniej odkryto u podnóża lodowca Mer de Glace szczątki ciał, co jeszcze przedłużyło pamięć o katastrofie. Kolejne fragmenty zwłok lodowiec zwracał przez następne lata, ten fakt odbił się głośnym echem i dał wydarzeniu niejako drugą młodość. Legenda wypadku przyczyniła się w dużej mierze do powstania mitu o śmier- 
cionośnej mocy Alp i zarazem wzbudziła pragnienie zmierzenia się z niebezpieczeństwem. Miała też inne, obok mitograficznych, konsekwencje. W trzy lata po wypadku władze zakazały drogi (zwanej ancien passage) na Mont Blanc, którą szła wyprawa doktora Hamela (dwa lata wcześniej szedł nią Antoni Malczewski). W tym samym roku powstało Towarzystwo Przewodników z Chamonix, które, odnosząc się explicite w swej konstytucji do wypadku, określało dobitnie swe obowiązki i prawa ${ }^{30}$.

\section{JAK INFORMOWAĆ O KATASTROFIE: PRASA}

Materiał w tej domenie jest ogromny, prześledziłem na próbę nieco roczników „Gazety Warszawskiej” na przestrzeni półwiecza. To niemało czasu, między - operującymi sensacyjnym na pierwszy rzut oka szczegółem - informacjami o trzęsieniu ziemi i wybuchu wulkanu w 1812 roku a dokładną, drukowaną w odcinkach naukową teorią wulkanologiczną z 1859 roku zdążył się zmienić świat i zasób wiedzy. We wczesnych rocznikach uderza spora liczba wiadomości o kataklizmach (jak wielkie burze) w bardzo skąpej rubryce niepolitycznych wiadomości ze świata. Dość często używa się określeń „nieszczęście” i „okropny”:

Dnia 24 [...] niedaleko Budy na przewozie do wyspy Csepoly [sic!] [...] zdarzył się okropny przypadek. Z przebywających rzekę promem przeszło 100 ludzi i około 20 koni większa połowa [...] zatonęła. Resztę wyratowali przecie pospieszający na pomoc rybacy. Przyczyna tego nieszczęścia nie jest jeszcze wiadomą. ${ }^{31}$

Dalej pojawia się fraza: „znaleźć grób w bałwanach”. Relacja z trzęsienia ziemi w Rzymie w 1812 roku oparta jest zaś na epizodach i szczegółach, a mniej na ogólnych informacjach. To typowy sposób sprawozdawania w tamtych czasach, ale mimo komiczno-makabrycznych nieraz detali nie odnosi się wrażenia, by redaktorzy wzmagali sensacyjność zdarzenia. Chcą po prostu przekazać wszystko, co wiedzą:

Wczoraj o 3 po północy dało się tu uczuć trzęsienie ziemi tak mocne, jak już dawno w tym kraju nie było. Ogólnie mówiąc, wszystkie fabryki mniej więcej ucierpiały. Kilka kloców kamiennych z gzemsów Koliseum [sic!] wypadło [...] Niedaleko zamku św. Anioła umarła kobieta ze strachu. Za bramą św. Pawła rozwalił się dom wiejski, którego gruzy przywaliły ojca z dwoma dziećmi. ${ }^{32}$

Kilka dni później „Gazeta Warszawska” podaje dalsze fakty:

30 Por. M. Tailland, 1820 , première tragédie alpestre: l'avalanche de la caravane du Docteur

Hamel, w: Récits et représentations des catastrophes..., s. 51-66.

31 „Gazeta Warszawska” 1812, nr 49 z 20 czerwca, s. 858.

32 Tamże, nr 33 z 25 kwietnia, s. 578. 
Kobietę u rzeźbiarza mieszkającą spotkał szczególniejszy przypadek. Ze strachu schowała głowę między dwie poduszki. W chwilę potem upadł na łóżko posąg Herkulesa przy łóżku stojący i gdyby nie poduszki, pewno by kobietę o śmierć był przyprawił. Donoszą od brzegów, że w czasie trzęsienia ziemi morze strasznie było wzburzone. Zwierzęta żałosne wydawały ryki. Nazajutrz jeszcze nawet koty wpadały w konwulsje i odurzone padały. ${ }^{33}$

„Gazeta Warszawska” to poważna instytucja. W kreowaniu prawdziwego nastroju sensacji wokół katastrof dużą rolę odgrywają almanachy i przede wszystkim tak zwane canard, czyli wspomniane druki ulotne, które powstały w drugiej połowie XVIII wieku i rozwijały się przez kolejnych kilkadziesiąt lat. Wytworzyły one - nieraz dzieląc wieści na odcinki, niczym powieść - brukową narrację o katastrofach będących ich głównym tematem, a często racją bycia. Warto zauważyć rosnącą rolę ikonografii, obowiązkowej od końca lat trzydziestych. Na przykład podczas wielkich powodzi, które nawiedziły Lyon w 1840 roku, ilustracje pokazują Rodan, którym spływają wymieszane trupy ludzi i koni, a w tle rysowanym niczym dekoracja w teatrze ulicznym widać trzy postacie wykonujące patetyczne gesty rozpaczy.

\section{KATASTROFA PRZYSZŁOŚCI}

Norwid jako jeden z pierwszych w literaturze dziewiętnastowiecznej posłużył się alegorią katastrofy do krytyki naocznej i przyszłej cywilizacji. Od katastrofy geologicznej w ciągu niecałego półwiecza przechodzimy do katastrofy technologicznej. Sześć lat przed Norwidowskim opowiadaniem, czyli w roku śmierci Mickiewicza, ukazała się w Paryżu niewielka książka adwokata Eugène’a Huzara, zatytułowana La fin $d u$ monde par la science. Zostaje w niej wyłożona prawdopodobnie pierwsza w ogóle teoria katastrofizmu technologicznego ${ }^{34}$. Książka odniosła duży sukces, dwa lata później Huzar rozwinął swe tezy w kolejnym dziele L’Arbre de la vie. Przeprowadza on mocną krytykę idei postępu, lecz nie czyni tego z pozycji konserwatywnych - takich czy innych. Dostrzega natomiast rozziew istniejący między możliwościami technicznymi a umiejętnością przewidywania. Ta nierównowaga - prorokuje - wywoła w przyszłości katastrofalne skutki. Niektóre z nich usiłuje przewidzieć, wiele brzmi dziś komicznie. Kto wie, czy nie zostanie wymyślona substancja zdolna podpalić wodę - gdyby wylała się przypadkowo do jakiegoś strumienia, mogłaby spowodować pożar oceanów. Ale niekiedy Huzar mierzy celnie: za sto, dwieście lat lasy zostaną przetrzebione i wobec miliardów

33 Tamże, nr 39 z 16 maja, s. 695.

34 Wykorzystuję w tym podrozdziale informacje zawarte w artykule: J.B. Fressoz, Eugène Huzar et l'invention du catastrophisme technologique, «Romantisme» 2010, $\mathrm{n}^{\circ} 150$. 
metrów sześciennych paliwa, które będzie na ziemi używane, harmonia świata zostanie zaburzona. Ważniejsze jest wszak co innego: to nie on ma dowodzić możliwości katastrof, to uczeni i inżynierowie mają wykazać nieszkodliwość swych wynalazków. Trzeba myśleć - sugeruje Huzar - o katastrofie jako o pewniku, po to, aby walczyć o jej uniknięcie.

Huzar konstruuje małą utopię: zbiór środków mających zapobiec przyszłej katastrofie. Na przykład proponuje utworzyć światowy rząd naukowców, mający studiować projekty wielkich prac mogących naruszyć harmonię świata. Jednak jest bezwzględnym katastrofistą - do swych tekstów wykorzystuje idee wiecznego powrotu, powtarzających się cyklów. Przyszła katastrofa jest pewna, gdyż już się zdarzała.

Kariera książek Huzara była błyskawiczna i zadziwiająca. Niewiele się o tym dotąd mówiło, a miały one spory wpływ na literaturę piękną. Pojawiają się teksty, jak Les Ruines de Paris Josepha Mery'ego, odnawiające romantyczny topos kontemplacji ruin (u Mery'ego są to ruiny Paryża w 3509 roku). Gustave Doré rysuje w tym czasie ruiny Londynu przyszłości, oglądane przez podróżnika z Nowej Zelandii. Wszystko to składa się na rodzaj „archeologii przyszłości”. Flaubert odwołaniem się do książki Huzara miał zakończyć Bouvarda i Pécucheta.

Huzarowi zawdzięczać można to, że w różnych sporach dotyczących rozwoju cywilizacyjnego dostrzegał nieodmiennie proces wytwarzania niepewności. Katastrofa odchodzi od geologii, odchodzi nawet od natury, by stać się katastrofą z nadania ludzkiego. Pokazuje, że pozytywistyczna nowoczesność, spadkobierczyni kartezjańskiego projektu technicznego panowania nad przyrodą, myśląca o zdobyczach techniki bez rozważania daleko idących następstw, była już wadliwa w chwili narodzin rewolucji przemysłowej. Huzar postulował - by użyć tytułu jednej z najnowszych i najgłośniejszych książek o katastrofie autorstwa Jeana-Pierre’a Dupuy ${ }^{35}$ - światły katastrofizm. Był romantykiem. Nie jest romantykiem ten, kto nie widzi katastrofy na horyzoncie. Ale mimo to wierzył w zaradczość, w możliwości jej uprzedzenia, w - jak mówił Mickiewicz - przedsiębiorczość. Był więc romantykiem kompletnym. Perspektywa katastrofy na horyzoncie i próby jej opanowania - to jest romantyczne i w tym sensie wszyscy dziś jesteśmy romantykami.

Co nie znaczy, że jesteśmy realistami, zwłaszcza na Krakowskim Przedmieściu. Wracam jeszcze na chwilę do „Gazety Warszawskiej”. Autor zamieszczonej w niej bardzo negatywnej recenzji Pani Bovary nie może pojąć, dlaczego powieść ta uznawana jest za dzieło realizmu: 
Arcytypem dla mnie realizmu jest dzieło polskie, wyszłe za granicą, z ducha najprzeciwniejsze demokracji, a które Mickiewicz tak wysoko podniósł w swych kursach; wyprzedziło ono o dwadzieścia lat realizm francuski, nie mający nigdzie na końcu swych utworów Galilaee, vicisti! i któremu słuszniej mogą służyć za epigraf słowa Miltona Bottomless perdition [bezdenne zatracenie - M.B]. ${ }^{36}$

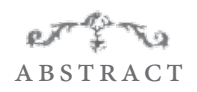

The Writing of Disaster in the Nineteenth Century. Introduction to Discussion

The article serves as a preliminary determination of the subject of disaster in the nineteenth century, explores different ways in which disaster existed in Romantic imagination and various attempts of its registration: literary, philosophical, press. It briefly describes the various dimensions of catastrophic discourse in the first half of the nineteenth century, associated with geological discoveries and their impact on Romantic historiosophy. It explores media and political processing of disasters and their existence in collective memory. It keeps track of various types of disasters associated with the development of civilisation and progressive approach to understand disaster also as an effect of civilisation hypertrophy, and not just the work of nature.

\section{KEYWORDS}

disaster, geology, Flood, civilisation, accident, end of the world, risk society

36 J. Zam... [Leonard Rettel], Korespondencja „Gazety Warszawskiej”. Paryż, 15 stycznia 1859 r., „Gazeta Warszawska” 1859, nr 44 z 4 (16) lutego, s. 3. 